11 - ORIGINAL ARTICLE

INVESTIGATIVE SURGERY

\title{
Clinical importance and prevalence of testicular microlithiasis in pediatric patients ${ }^{1}$
}

\author{
Importância clínica e prevalência de microlititíase testicular em pacientes pediátricos
}

\author{
Robson Azevedo Dutra', Adriana Cartafina Perez-Bóscollo", Edilaine Cristian Melo"II, João Celso Cruvinel ${ }^{\mathrm{III}}$ \\ ${ }^{1} \mathrm{PhD}$, Associate Professor, Pediatric Surgery, Department of Surgery, UFTM, Uberaba-MG, Brazil. Collect the data, performed the statistical analysis \\ and wrote the manuscript. \\ "PhD, Full Professor, Pediatric Surgery, Department of Surgery, UFTM, Uberaba-MG, Brazil. Conception, design and responsible for the surgical \\ procedures. \\ ${ }^{11 \prime}$ MD, Graduate Student, UFTM, Uberaba-MG, Brazil. Involved in the design, collect of data and helped to draft the manuscript.
}

\begin{abstract}
PURPOSE: To evaluate the prevalence of testicular microlithiasis among pediatric patients with inguinoscrotal affections.

METHODS: Between January 2005 and January 2010, we evaluated, prospectively 1504 children ranging from 1 to 15 years with inguinoscrotal affections with a high-frequency ultrasound system, which employs a 10-MHz transducer.

RESULTS: Testicular microlithiasis was identified in 20 testes of eleven children $(0.71 \%$ of 1504 patients evaluated), through an ultrasound scan. Testicular microlithiasis was found in 5 children with cryptorchidism (3.93\% of 127 patients), 4 children with retractile testes (14.8\% of 27 patients), 1 child with a hypotrophic testis (100\% of 1 patient), and 1 child with inguinal hernia (0.07\% of 1349 patients). The children with testicular microlithiasis were submitted to annual physical examinations and ultrasound evaluations.
\end{abstract}

CONCLUSIONS: Testicular microlithiasis was a rare condition and occurred in $0.7 \%$ of the subjects studied. The association with cryptorchidism, retractile and hypotrophic testis was significant.

Keywords: Testis, Lithiasis, Ultrasound, Cryptorchidism, Testicular neoplasms.

\section{RESUMO}

OBJETIVO: Avaliar a prevalência de microlitíase testicular entre pacientes pediátricos com afecções inguinoescrotais.

MÉTODOS: Estudo prospectivo entre janeiro de 2005 a janeiro de 2010, utilizando ultrasonografia escrotal em 1504 crianças (de 1 a 15 anos) com afecções inguinoescrotais.

RESULTADOS: Microlitíase testicular foi identificada em 20 testículos de 11 crianças (0,71\% dos 1504 pacientes). 5 crianças com criptorquidia (3,93\% de 127 pacientes), 4 com testículo retrátil (14,8\% de 27 pacientes), 1 com hipotrofia testicular e 1 com hérnia inguinal (0,07\% de 1349 crianças). As crianças foram avaliadas anualmente com exame físico e ultrassonografia inguinoescrotal.

CONCLUSÕES: A microlitíase testicular é uma entidade rara, ocorrendo em $0,7 \%$ dos pacientes pediátricos com afecções inguinoescrotais. A associação com a criptorquidia, testículo retrátil e a hipotrofia testicular foi significativa.

Descritores: Testículo, Litíase, Ultrassonografia, Criptorquidismo, Tumor de testículo. 


\section{Introduction}

Testicular microlithiasis (TM) is rare. However, it has come to be encountered more frequently due to the increased number of situations in which high-resolution ultrasound is used in the inguinoscrotal region to investigate testicular size in cryptorchidism or patency of the peritoneal-vaginal duct. The typical presentation of TM is diffuse calcification (consisting of hydroxyapatite crystals surrounded by layers of collagen fibers) in the seminiferous tubules. There is evidence that

TM is a precursor of testicular germ cell tumors ${ }^{1,2}$ and that it is associated with infertility ${ }^{3}$. However, it remains unknown whether these are true cause-and-effect relationships or just incidental findings. The incidence of TM is from 0.6 to $5.6 \%$ in the general population, from 0.6 to $9 \%$ in the population reporting to experts, and from 0.8 to $20 \%$ among individuals with fertility problems ${ }^{4}$. The incidence of TM concomitant with testicular germ cell tumors ranges from 8 to $46 \%{ }^{4}$.The aim of the study was to evaluate the prevalence of TM among pediatric patients with inguinoscrotal affections.

\section{Methods}

Between January 2005 and January 2010, we evaluated, prospectively 1504 children ranging from 1 to 15 years (mean age: 7,5 ). The children with cryptorchidism, retractile testis, hypotrophy of the testis, and inguinal hernia were submitted to ultrasound scans of the testis. The follow-up period ranged from 6 months to 5 years.

Research Ethics Committee of Triangulo Mineiro Federal University approval was obtained. An experienced specialist operated the high-frequency ultrasound system (Power Vision 6000, Toshiba), which employs a $10-\mathrm{MHz}$ transducer. TM was characterized as distributed hyperechogenic microliths measuring less than $3 \mathrm{~mm}$ in diameter and seen in a single ultrasound scan. The distribution of the calcifications was diffuse or focal, uni or bilateral (Figure 1).

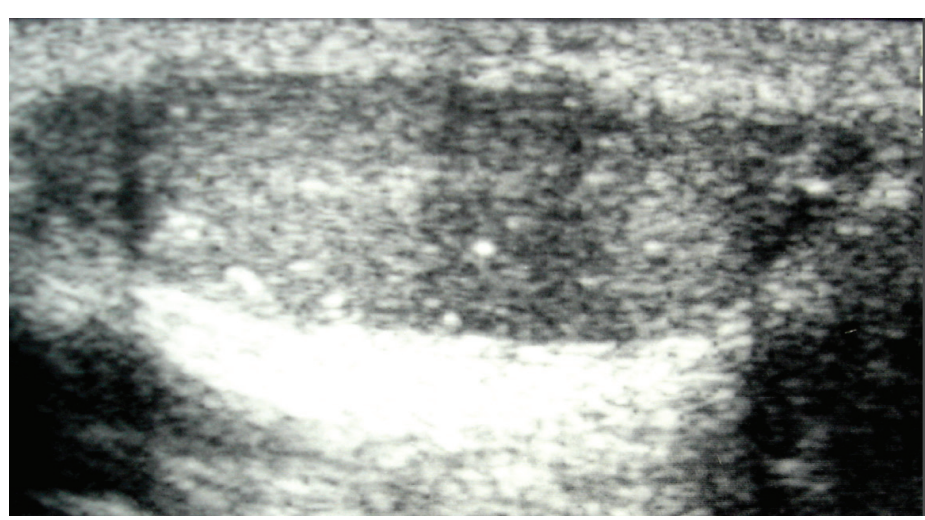

FIGURE 1 - Testicular ultrasound scan: microlithis (arrows) without acoustic shadows observed in the left testis of a 10 years old boy.

\section{Results}

Among the 1504 children evaluated, 127 patients (8.44 $\%)$ had cryptorchidism, 27 patients $(1.79 \%)$ had retractile testis, 1 patient $(0.06 \%)$ exhibited hypotrophy of one testis without any other co-morbidity, and 1349 patients (88.69\%) presented with inguinal hernia. A total of 20 testicles in 11 children $(0.73$ $\%$ ), had an ultrasound diagnosis of typical TM. We observed that 5 children with cryptorchidism (3.93\% of 127 patients), 4 children with retractile testis (14.8\% of 27 patients), 1 child with testis hypotrophy (100\% of 1 patient), and 1 child with inguinal hernia ( $0.07 \%$ of 1349 patients) had TM. Nine children (4 with cryptorchidism, 4 with retractile testis and 1 with inguinal hernia) had bilateral disease. The relative risk of testicular microlithiasis calculated for patients with retractile testicle, cryptorchidism, testicular hypotrophy, and inguinal hernia were respectively 36.58 , 9.88, 79.11 and 0.01 . These children were submitted to annual follow-up with physical examinations and ultrasound evaluations. The co-occurrence of TM with testicular tumors was not found in this study of pediatric patients. (Table 1) 
TABLE 1 - Percentual of testicular microlithiasis in 1504 children with inguinoescrotal affections.

\begin{tabular}{cccccc}
\hline & $\begin{array}{c}\text { Inguinoscrotal } \\
\text { Affections }\end{array}$ & $\begin{array}{c}\text { Testicular } \\
\text { Microlithiasis } \\
\text { (N }{ }^{\circ} \text { Children) }\end{array}$ & $\begin{array}{c}\text { Testicular } \\
\text { Microlithiasis } \\
\text { (Side } \\
\text { Affected) }\end{array}$ & $\%$ & $\begin{array}{c}\text { Relative } \\
\text { Risk }\end{array}$ \\
\hline $\begin{array}{c}\text { Cryptorchidism } \\
\text { Retractile } \\
\text { Testes }\end{array}$ & 127 & 5 & $\begin{array}{c}\text { 4: Bilateral } \\
\text { 1: Unilateral }\end{array}$ & $3,93 \%$ & 9.88 \\
\hline $\begin{array}{c}\text { Hypotrophic } \\
\text { Testis }\end{array}$ & 1 & 4 & $\begin{array}{c}\text { 4: Bilateral } \\
\text { (2 children } \\
\text { with Down } \\
\text { Syndrome) }\end{array}$ & $14,8 \%$ & 36.58 \\
\hline $\begin{array}{c}\text { Inguinal Hernia } \\
\text { Total }\end{array}$ & 1349 & 1 & Unilateral & $100 \%$ & 79.11 \\
\hline & 1504 & 11 & Bilateral & $0.07 \%$ & 0.01 \\
\hline
\end{tabular}

\section{Discussion}

High-resolution inguinoscrotal ultrasound is a sensitive diagnostic tool, especially when high-frequency linear transducers are used. It has come to be more widely used in recent years due to improvements in the quality of ultrasound equipment. Inguinoscrotal ultrasound can identify scrotal calcifications, which can be either intratesticular or extratesticular. Extratesticular scrotal calcifications are more common and are associated with inflammation of the epididymis and tunica albuginea. Smaller intratesticular scrotal calcifications can be characterized as $\mathrm{TM}$, whereas larger ones are typically secondary to phlebolith, spermatic granulomas, vascular calcification, or tumors. Those that cast an acoustic shadow are therefore not considered characteristic of $\mathrm{TM}^{5,6}$, which is defined as five or more randomly distributed hyperechogenic microliths measuring less than $3 \mathrm{~mm}$ in diameter and seen in a single ultrasound scan. The distribution of the calcifications can be diffuse or focal, and the TM can be unilateral or bilateral. The most common form of presentation is tiny specks of echogenic foci distributed diffusely, bilaterally, and symmetrically within the testicular parenchyma ${ }^{1,7}$. This pattern of presentation was found in our study. The disease was diffusely distributed and bilateral in 9 of 11 children.

Although there is no known cause of TM, it is thought to result from a degenerative process in the seminiferous tubule epithelium. This process produces cellular debris that migrates to the lumen of the seminiferous tubules and seeds the calcification ${ }^{8}$.

A review of the literature showed that the true incidence of $\mathrm{TM}$ ranges from $00.4 \%$ in autopsies to $18.1 \%$ in ultrasound examinations ${ }^{9}$. In our study, we found the prevalence of TM among pediatric patients with inguinoscrotal affections to be $0.71 \%$.

There is no consensus regarding the predictive value of TM for the appearance of testicular germ cell tumors. It has been reported that $45 \%$ of patients diagnosed with TM also have testicular germ cell tumors ${ }^{10}$. In addition, one group of authors identified TM in $15 \%$ of patients who underwent orchiectomy for testicular cancer ${ }^{11}$.

TM has been shown to be correlated with conditions such as atrophic testis; varicocele; testicular torsion; sympathetic nervous system calcifications; cerebral calcifications; pseudohermaphroditism; Down's syndrome; Klinefelter's syndrome; cystic fibrosis; germ cell tumors; and carcinoma in situ ${ }^{9}$.

Höbarth et al. ${ }^{1}$ found testicular tumors in $5(44 \%)$ of 11 cases of TM. Otite et al. ${ }^{12}$ conducted a retrospective evaluation of 3,026 patients who underwent inguinoscrotal ultrasound investigation of pain, edema, or infertility. The authors found that $54(1.77 \%)$ presented TM, and that $16(30 \%)$ of those were diagnosed with testicular tumors.

Up to $10 \%$ of children with cryptorchidism also present $\mathrm{TM}$, which is double the TM incidence reported in children with descended testes ${ }^{13}$. Cryptorchidism is also a risk factor for testicular cancer, as perhaps evidenced by variations in the incidence of TM: $1 \%$ in inguinal testes; $5 \%$ in abdominal testes; and up to $25 \%$ in bilateral cryptorchid testis. Long-term follow-up evaluation of such children is therefore a priority ${ }^{14}$.

In the present study with pediatric patients, the undescended testes were all located at the inguinal region. We found that $3.93 \%$ of these undescended testes had TM. We observed a significant association between retractile testes and TM (14.8\% of 27 patients with retractile testes had TM). Patients with cryptorchidism had an increased risk of testicular microlithiasis provided in 36 times. Patients with retractile testicle this risk was increased by almost 10 times. Conversely, patients with inguinal hernia have the risk to present with testicular microlithiasis extremely reduced. With regard to patients with testicular hypotrophy, the fact that the single carrier of this disease, in this study, be provided with testicular microlithiasis suggests that this result must be considered with some reservation. The relative risk of 79.11 is probably not consistent with reality. These data suggest that these subjects with retractile testes or cryptorchidism may be evaluated with ultrasound scan. The co-occurrence of TM with testicular tumors was not found in this study.

The exact relationship between TM and infertility remains unknown. It is thought that reductions in sperm count 
are attributable to TM-related obstruction of the seminiferous tubules, which present concretions in $30-60 \%$ of patients with TM. Such patients can also present a significant reduction in sperm motility, resulting in impaired sperm migration and contributing to male infertility ${ }^{7}$. In contrast, infertility in patients with TM has been shown to be secondary to testicular dysgenesis and other concomitant testicular abnormalities ${ }^{4}$. This study group consisted of pediatric patients, so no association with infertility could be extracted from this study.

There is no consensus regarding proper follow-up of patients with TM. Ultrasound periodicity is every three to six months or annually, being indicated more often in patients presenting focal lesions within the testicular parenchyma and undergoing testicular biopsy ${ }^{11,12}$. The children evaluated in the present study with TM, underwent annual follow-up evaluations with physical examination and ultrasound scan at the Pediatric Surgery Outpatient Clinic. In agreement with the literature on the association of TM with germ cell tumors, we emphasize the importance of long-term follow-up of these subjects.

\section{Conclusions}

Testicular microlithiasis (TM) was a rare condition and occurred in $0.7 \%$ of the subjects studied. TM had a significant association with cryptorchidism, retractile and hypotrophic testis. As this study is composed of a pediatric population no correlation with infertility could be extracted. The co-occurrence of TM with testicular tumors was not found.

\section{References}

1. Höbarth K, Susani M, Szabo N, Kratzik C. Incidence of testicular microlithiasis. Urology. 1992;40:464-7.

2. Backus ML, Mack LA, Middleton WD, King BF, Winter TC 3rd, True LD. Testicular microlithiasis: imaging appearances and pathologic correlation. Radiology. 1994;192:781-5.

3. Ganem JP, Workman KR, Shaban SF. Testicular microlithiasis is associated with testicular pathology. Urology. 1999;53:209-3.

4. Sakamoto H, Shichizyou T, Saito K, Okumura T, Ogawa Y, Yoshida H, Kushima M. Testicular microlithiasis identified ultrasonographically in Japanese adult patients: prevalence and associated conditions. Urology. 2006;68:636-41.

5. Bushby LH, Miller FN, Rosairo S, Clarke JL, Sidhu PS. Scrotal calcification: ultrasound appearances, distribution and aetiology. $\mathrm{Br}$ J Radiol. 2002;75:283-8.

6. Miller FN, Rosairo S, Clarke JL, Sriprasad S, Muir GH, Sidhu PS. Testicular calcification and microlithiasis: association with primary intra-testicular malignancy in 3,477 patients. Eur Radiol. 2007; 17:363-9.

7. Thomas K, Wood SJ, Thompson AJ, Pilling D, Lewis-Jones DI. The incidence and significance of testicular microlithiasis in a subfertile population. Br J Radiol. 2000;73:494-7.
8. de Gouveia Brazao CA, Pierik FH, Oosterhuis JW, Dohle GR, Looijenga LH, Weber RF. Bilateral testicular microlithiasis predicts the presence of the precursor of testicular germ cell tumors in subfertile men. J Urol. 2004;171:158-60.

9. Guzmán Martínez-Valls PL, Hita Villaplana G, Fernandez F. Significance and management of testicular microlithiasis. Arch Esp Urol. 2003;56:472-7.

10. Furness PD 3rd, Husmann DA, Brock JW 3rd, Steinhardt GF, Bukowski TP, Freedman AL, Silver RI, Cheng EY. Multiinstitutional study of testicular microlithiasis in childhood: a benign or premalignant condition? J Urol. 1998;160:1151-4.

11. Bach AM, Hann LE, Shi W, Giess CS, Yoo HH, Sheinfeld J, Thaler HT. Is there an increased incidence of contralateral testicular cancer in patients with intratesticular microlithiasis? Am J Roentgenol. 2003; 180:497-500.

12. Otite U, Webb JA, Oliver RT, Badenoch DF, Nargund VH. Testicular microlithiasis: Is it a benign condition with malignant potential? Eur Urol. 2001;40:538-42.

13. Husmann DA. Cryptorchidism and its relationship to testicular neoplasia and microlithiasis. Urology. 2005;66:424-6.

14. Campbell HE. The incidence of malignant growth of the undescended testicle: a reply and re-evaluation. J Urol. 1959;81:663-8.

\section{Correspondence:}

Robson Azevedo Dutra

Av. Lázaro de Souza Campos, 990

14401-295 Franca - SP Brasil

Tel: (55 16)9117-0094

robsonmarcia@netsite.com.br

Received: February 23, 2011

Review: April 25, 2011

Accepted: May 20, 2011

Conflict of interest: none

Financial source: none

${ }^{1}$ Research performed at Outpatient Clinic of Pediatric Surgery, Department of Surgery, Triangulo Mineiro Federal University (UFTM), Uberaba-MG, Brazil. 